\title{
Peripheral edema: diagnostics and treatment
}

Prof. L.V. Zhuravlyova , PHD A.A. Yankevich

In this review discussion was focused on edema - the common presentation of internal diseases, neurological disorders and surgical problems. Edema is defined as abnormal accumulation of interstitial fluid, which can be either due to excessive capillary filtration or ineffective lymphatic drainage. There are systemic and local causes of edema, which should be revealed promptly, because specific etiology has significant impact on the approach to treatment. Among common causes of edema chronic venous insufficiency, heart failure, nephritic syndrome, effects of drugs, deep venous thrombosis and etc. were analyzed. Some attention was paid to specific conditions like idiopathic edema and lipidema (which is abnormal fat distribution). Diagnostic procedures and treatment options became the features of consideration regarding its effect on the management of patient with peripheral edema. In addition to the descriptive part of the article, the multi-choice questions were proposed for self-assessment.

Key Words: peripheral edema, diagnostic procedures, treatment options.

Контактна інформація: Журавльова Лариса Володимирівна зав. кафедрою кафедра внутрішньої медицини №3 ХНМУ, доктор медичних наук, професор. м. Харків, пр. Правди, 17, р. т. (057) 705-66-59, e-mail: 1.zhuravlyova@mail.ru.

Стаття надійшла до редакції 20.10.2014 p.

\section{ПИТАННЯ НЕВРОЛОГІЇ. СИМПОЗІУМ}

УДК $618.17-008.8(616-053.7) 7616.12-008.331$.
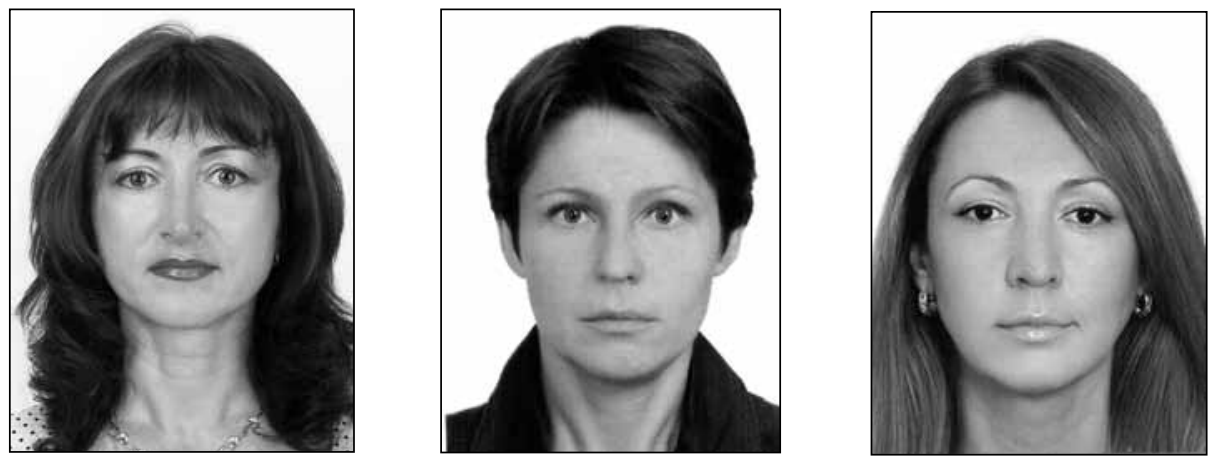

\section{Проф. Т.А. Літовченко, доц. О.Л. Тондій, доц. О.П. Завальна}

Харківська медична академія післядипломної освіти

Кафедра неврології

\section{Мікування неврологічних розмадів у жінок в період пре- та менопаузи}

\section{з використанням компмексних гомеопатичних препаратів}

$\mathrm{B}$ зв’язку з подовженням тривалості життя все більш актуальними стають медико-соціальні аспекти, пов'язані з менопаузою. Згідно прогнозів Всесвітньої організації охорони здоров'я, до 2015 р. близько $46 \%$ жіночого населення планети дійде віку 45 років й більше, причому 85\% з них стикнуться з проблемами перименопаузального періоду, якому притаманні такі прояви климактеричного синдрому (КС), як вазомоторні й психоемоціональні розлади $[1,3-5,8,10$,
11]. Ці симптоми, що розвиваються у більшості жінок працездатного віку, стають перешкодою для ведення звичного способу життя, знижують якість життя, працездатність і нерідко призводять до проблем в сім'їй на роботі $[1,3-5,8,10-13]$. У сучасних умовах, у зв'язку із збільшенням загальної тривалості життя й відносним поліпшенням соціально-побутових умов, час настання менопаузи відсунувся на $5-8$ років, порівнюючи $з$ початком століття. Середній вік настан- 
ня менопаузи в даний час складає 46 років 8 місяців, i тому практично $1 / 3$ свого життя жінка проводить у стані постменопаузи $[4,5]$.

Питання климактерія протягом багатьох років привертають увагу вчених усіх країн, адже гормональна перебудова репродуктивної системи супроводжується розвитком патологічних змін у різних органах і системах, особливо в серцево-судинній, нервовій, ендокринній, кістково-м'язовій $[1,3-5,11]$.

Клімактеричний період в цілому можна розглядати як період складної вікової перебудови, в першу чергу, нейрогуморальної регуляції, пов'язаної зі згасанням репродуктивної функції. Клімактеричний період (КП) виникає як у жінок, так і у чоловіків, але у чоловіків він настає пізніше, розвивається повільніше. У жінок КП починається раніше, протікає гостріше, і набагато яскравіше виражений [3-5, 10-13], що обумовлює більшу доступність його дослідження.

Клімакс - загально-медична проблема, вивченням якої займаються лікарі багатьох спеціальностей, насамперед ендокринологи, гінекологи, сексопатологи, невропатологи, терапевти, лікарі загальної практики - сімейної медицини та інші. Зазвичай клімакс у жінок настає у віці 45-55 років, у чоловіків в 45-60 років. Чоловіки рідше звертаються до лікаря $з$ приводу клімактеричних скарг, а лікарі в свою чергу рідко пояснюють скарги хворого змінами в організмі, притаманними для климакса. Час настання клімакса залежить від типу нервової діяльності людини, перенесених у минулому захворювань, фізичного розвитку, способу життя та багатьох інших факторів. Явища клімакса розвиваються поступово і в нормі малопомітно проходять протягом $1-5$ років. У частини людей порушення нервової діяльності й зміна функцій залоз внутрішньої секреції спостерігаються за кілька років до припинення менструації та згасання статевої функції. При цьому вони супроводжуються різними хворобливими проявами (патологічний клімакс) . У жінок закінчення місячних і початок клімаксу часто не збігаються. Зазвичай зміна в яєчниках починається пізніше - вже після того, як протягом кількох років хворі пред'являють скарги клімактеричного характеру [3-5].

Клімакс, що настає до 40 років, вважається раннім. При цьому вже в $36-40$ років можуть спостерігатися зниження рухової активності, неприємні відчуття в області серця, серцебиття, припливи жару до голови, озноб. Часто з’являється надмірна повнота, іноді підвищується артеріальний тиск. Настанню раннього клімаксу сприяють коморбідні гострі та хронічні хвороби, часті пологи й аборти, запальні захворювання статевої сфери тощо [3-5, 10, 11].

У методичних рекомендаціях відображені сучасні дані про етіопатогенез, класифікацію, особливості клінічної картини неврологічних проявів клімактеричного синдрому, дані додаткових методів обстеження, нейрофізіологічного обстеження, підходи до лікування. Методичні рекомендації призначені для лікарів-неврологів, терапевтів, лікарів загальної практики - сімейної медицини, ендокринологів,гінекологів, лікарів-інтернів.

\section{Етіопатогенез та класифікація}

За вираженістю процесів, що відбуваються в організмі, клімакс поділяють на стадії:

1. Пременопауза - період від початку згасання гормональної функції яєчників до повного припинення менструацій. Починається пременопауза в середньому в $40-45$ років і триває від 2 до 6 років. Однак початок пременопаузи, як вказує ряд джерел, в останнє десятиліття «молодіє» і починається в середньому в $37-38$ років.

2. Менопауза - остання спонтанна менструація. Якщо місячні припиняються і не дають про себе знати як мінімум рік, значить, менопауза вже настала.

3. Постменопауза - період від останньої менструації до останнього дня життя жінки. У цей період продуціювання яєчниками гормонів зовсім припиняється, рівень естрогенів стабільно низький. При нормальному перебігу клімаксу діяльність репродуктивної системи припиняється поступово, й організм встигає адаптуватися до вказаних змін, самопочуття залишається нормальним довгий час [ $3-5,10,11]$.

Клімактеричні розлади, що виникають в результаті дефіциту естрогенів, посилюють зміни в організмі жінки, що з'являються ще в пременопаузі, та характеризуються, в основному, комплексом вегетососудинних проявів (приливи жару, підвищена пітливість, головні болі, озноб, напади серцебиття та ін), обмінно-ендокринних (збільшення маси тіла, коливання цифр артеріального тиску (АТ), сухість і старіння шкіри, ламкість нігтів, випадіння волосся тощо) і психоемоційних (дратівливість, сонливість або безсоння, слабкість, занепокоєння, депресія, забудькуватість, неуважність, зниження лібідо та ін) проявів. Пізніше, при більш глибокому естрогенному дефіциті, з'являються урогенітальні й пізні обмінні порушення (остеопороз, серцево-судинні захворювання, порушення обміну речовин тощо) $[3-5,10,11]$.

Таким чином, клімактеричний синдром (клімакс) - це комплекс судинних, неврологічних і психоемоційних порушень, обумовлених гормональними змінами в організмі жінки в перименопаузі (віці близько останньої менструації). Даний стан $€$ «перехідним» для жінок від фертильного віку до постменопаузи, коли запліднення неможливе.

\section{Клінічні симптоми}

Ранні симптоми клімактеричного синдрому: припливи жару, озноби, підвищена пітливість, головні болі, підвищення або зниження тиску, прискорене серцебиття; дратівливість, сонливість, загальна слабкість, занепокоєння, депресія, забудькуватість, неуважність, зниження статевого потягу.

Через $1-3$ роки можуть з'явитися й інші неприємні симптоми клімаксу: біль у сечовому міхурі, печіння і свербіж в ділянці статевих органів, сухість шкіри, ламкість нігтів, зморшки, сухість і випадання волосся, можливе збільшення маси тіла.

До пізніх симптомів клімаксу відносять обмінні прояви, які можуть виникнути через п’ять і більше років після менопаузи: метаболічний синдром (ате- 
росклероз, підвищений тиск, ожиріння, інсулинорезистентність); неврологічні (зниження когнітивної функції, пам'яті, зору, слуху); кістково-м'язові (остеопороз, остеоартрит, що загрожує частими й складними переломами, навіть мимовольними) та ін. $[3-5,10,11]$.

Всі прояви клімактеричного синдрому обумовлені віковим зниженням рівня жіночих статевих гормонів - естрогенів. Зниження рівня цих гормонів призводить до порушення регуляції нервових центрів у головному мозку - центр терморегуляції, судинноруховий, серцевий і т. д., що проявляється в симптомах клімактеричного синдрому:

1. « Припливи " - найчастіший симптом клімаксу, з'являється у 50-55\% всіх жінок цього віку. Припливи являють собою вазомоторні «напади» - різке розширення дрібних судин шкіри. Клінічно це проявляється картиною раптового припливу жару до голови та верхньої половини тулуба. Найчастіше це відбувається вночі. Під час припливу можуть спостерігатися напади серцебиття, задишки, підвищення артеріального тиску. Іноді спостерігається непритомність, почуття нестачі повітря, нудота, запаморочення, слабкість.

За кількістю таких припливів визначають ступінь важкості клімактеричного синдрому:

- легкий ступінь - до 10 припливів без порушення загального стану і працездатності;

- середньої важкості - до 20 припливів на добу, зі скаргами на головний біль;

- важкий ступінь - понад 20 припливів на добу, що призводить до порушення працездатності.

2 . Неврологічні симптоми - головний біль, стани запаморочення, для яких характерна «метеочутливість» - частіше виникають при зміні погодних умов (температури, вологості, атмосферного тиску).

3. Психоемоційні симптоми - після «припливів» являються найпоширенішими. Жінки страждають від нестабільності настрою, позитивні емоції можуть різко змінюватися негативними. Дратівливість, плаксивість і занепокоєння - основні прояви клімактеричного періоду. Можуть мати місце порушення сну (порушення засинання, поверхневий сон), іноді дуже значні, що теж позначається на емоційному стані жінки. Зниження пам'яті й швидкості мислення $€$ причиною зниження «тонусу» кори головного мозку в перименопаузі.

До важких проявів клімактеричного синдрому відносять депресії й фобіі, які можуть становити безпосередню загрозу для життя жінки - саме в цей віковий період спостерігається сплеск суїцидів .

4. «Адреналові» симптоми - зустрічаються дещо рідше за даними літератури, пов'язані з множинними гормональними перебудовами і проявляються у вигляді «адреналових кризів», що супроводжуються головним болем, підвищенням артеріального тиску, відчуттям серцебиття, затримкою сечі. До цих же проявів клімактеричного синдрому відносять так звану клімактеричну кардіодістрофію - для неї притаманні болі в ділянці серця, що нагадують стенокардію [2-4, 6-14].
За клінічними проявами розрізняється фізіологічний та патологічний перебіг КП.

\section{Етапи лікування}

Лікування клімактеричного синдрому має декілька напрямків.

1. Здоровий спосіб життя: нормалізація добового біоритму, відмова від шкідливих звичок, підтримка певного режиму харчування й рухового режиму.

2. Замісна гормональна терапія (ЗГТ) - застосування препаратів, що містять жіночі статеві гормони, дуже ефективно знімає або істотно зменшує практично всі прояви клімактеричного синдрому.

3. Негормональні методи лікування - використовуються різні рослинні препарати для зменшення вираженості симптомів клімаксу.

4. Седативні препарати.

5. Вітаміни (група В, альфа-токоферол, аскорбінова кислота, вітамін D), мікроелементи (кальцій, магній, селен, цинк).

6. Антидепресанти та анксіолітики - необхідні при проявах депресії ( при стійкому зниженні настрою, «емоційній тупості », суїцідальних думках) .

7. Рослинні комплексні препарати, що містять фітоестрогени (препарати папороті та ін.)

8. Фізіотерапія та інші немедикаментозні методи лікування (гідротерапія: обливання, контрастний душ, гарячі ножні ванни, гаряча ванна з заспокійливими травами перед сном, радонові та йодобромні ванни).

9 . Масаж загальний і сегментарний, тонізуючий або релаксуючий.

10 . Рефлексотерапія: акупунктура, термопунктура, фармакопунктура.

11 .Симптоматична терапія - нейропротектори, вазоактивні препарати, венотоніки та ін. [ 7-9, 11, $12,14]$.

Не зважаючи на доведену ефективність замісної гормональної терапії для корекції неврологічних ускладнень клімактерію, такі препарати мають ряд протипоказань $[1,5]$. У зв'язку з цим актуальним $\epsilon$ використання альтернативних негормональних методів лікування КС, серед яких все більшу увагу фахівців привертають комбіновані стандартизовані екстракти рослин і гомеопатичні препарати $[15,16]$.

\section{Обгрунтування доцільності гомеопатичної терапії}

Препарат Цефавора ${ }^{\circledast}$ пропонує унікальну комбінацію 3-х активних речовин: Гінкго білоба + Омела біла + Глід. Ретельно підібране поєднання активних речовин, що доповнюють одна одну, сприяє поліпшенню діяльності центральної та периферичної нервової, серцево-судинної й ендокринної систем. Фармакологічні ефекти гомеопатичного застосування компонентів Цефавори представлені в табл. 1 [15].

Компоненти, що входять до складу препарату Цефавора, комплексно покращують мозкову, серцеву та периферичну мікроциркуляцію. Знижується агрегація еритроцитів, тромбоцитів і в'язкість крові, що призводить до поліпшення реологічних характе- 
ристик крові та швидкості кровотоку в капілярах. Поступово стабілізується проникність клітинних мембран, нейтралізується дія вільних радикалів, поліпшується утилізація кисню і глюкози. Зрештою, нормалізується серцевий, мозковий і периферичний кровообіг, поліпшується метаболізм в тканинах усіх органів і систем [15].

Таблиия 1

Компоненти, що входять до складу препарату Цефавора та їх дія

\begin{tabular}{|c|c|}
\hline Склад & Механізм дії та терапевтичний ефект \\
\hline $\begin{array}{l}\text { Гінкго } \\
\text { білоба } \\
\text { (Ginkgo } \\
\text { biloba) }\end{array}$ & $\begin{array}{l}\text { У крові відбувається зниження агрегації } \\
\text { еритроцитів і тромбоцитів. Це є причи- } \\
\text { ною зниження в'язкості крові, пов'язане з } \\
\text { поліпшенням характеристик і швидкості кро- } \\
\text { вотоку, особливо в капілярах. Проникність } \\
\text { капілярів нормалізується шляхом стабілізації } \\
\text { мембрани. У тканинах стимулюються про- } \\
\text { цеси поглинання та утилізації кисню й глю- } \\
\text { кози. Флавоноїди нейтралізують дію вільних } \\
\text { радикалів, які у великій кількості виділяються } \\
\text { в разі ішемії або порушень метаболізму, і за- } \\
\text { хищають організм від шкідливих наслідків } \\
\text { впливу радикалів. Нормалізація кровообігу } \\
\text { головного мозку й кінцівок відбувається без } \\
\text { проявів синдрому обкрадання }\end{array}$ \\
\hline $\begin{array}{l}\text { Омела біла } \\
\text { (Viscum Al- } \\
\text { bum L.) }\end{array}$ & $\begin{array}{l}\text { Сприяє нормалізації високого та низького } \\
\text { кров'яного тиску, зменшує прояви запаморо- } \\
\text { чення, коронарної вазоконстрикції, аритмій } \\
\text { серця }\end{array}$ \\
\hline $\begin{array}{l}\text { Глід (Cratae- } \\
\text { gus laevigata } \\
\text { and mo- } \\
\text { nogyna) }\end{array}$ & $\begin{array}{l}\text { Завдяки дилятації кровоносних судин } \\
\text { збільшується коронарний кровотік, що } \\
\text { поліпшує показники міокардіального крово- } \\
\text { току }\end{array}$ \\
\hline
\end{tabular}

\section{Власні спостереження}

На кафедрі неврології ХМАПО на базі Центральної клінічної лікарні Укрзалізниці нами були проведені дослідження та оцінка ефективності застосування комбінованого стандартизованого гомеопатичного препарату (в нашому випадку - Цефавора, «Cefak», Німеччина) в корекції вегетативних дистоній у жінок з цефалгічним синдромом в період пре- та менопаузи. Дане дослідження проведене в процесі виконання науково-дослідної роботи кафедри неврології ХМАПО «Патогенетичні та саногенетичні механізми в діагностиці, лікуванні та реабілітації хворих з больовими та іншими пароксизмальними порушеннями при ураженнях периферичної та центральної нервової системи» № реєстрації 0114U000519 від 14.01.2014 p.

Нами було обстежено 52 жінки, віком від 37 до 55 років, що знаходилися під спостереженням протягом 2-х місяців. У всіх пацієнток бралися до уваги вік, супутня патологія, наявність гінекологічних захворювань, рівень фізичної активності, наявність психоемоційного фактора, рівень освіти, сімейний стан, працездатність та ін. Наявність актуальної соматичної патології було критерієм виключення.

У пацієнток відзначалися фізіологічні порушення менструального циклу, пов'язані з клімактеричним періодом. Всі пацієнтки були оглянуті гінекологом, не отримували гормонзамісну терапію.
Пацієнтки були розподілені в залежності від віку та періоду клімактеричних проявів (див. табл. 2):

Таблиия 2

\begin{tabular}{|c|c|c|c|c|}
\multicolumn{5}{c}{ Розподіл пацієнток в групах } \\
\begin{tabular}{|c|c|c|c|} 
Вік жінок \\
(фаза)
\end{tabular} & $\begin{array}{c}\text { від } 37 \text { до } \\
45 \text { (преме- } \\
\text { нопауза) }\end{array}$ & $\begin{array}{c}\text { від } 45 \text { до } \\
55 \text { (мено- } \\
\text { пауза) }\end{array}$ & $\begin{array}{c}\text { від } 45 \text { до } 55 \\
\text { (постмено- } \\
\text { пауза) }\end{array}$ & Всього \\
\hline $\begin{array}{c}\text { Основна } \\
\text { група } \\
\text { (жін/\%) }\end{array}$ & 21 жін. & 8 жін. & 3 жін. 5,8\% & 32 жін. \\
$61,5 \%$ & $15,4 \%$ & & $20 \% і н$. \\
\hline $\begin{array}{c}\text { Кон- } \\
\text { трольна } \\
\text { група } \\
\text { (жін/\%) }\end{array}$ & $23,1 \%$ & $9,6 \%$ & 3 жін. 5,8\% & $38,5 \%$ \\
\hline
\end{tabular}

Враховуючи дані таблиці 2, пацієнтки з пременопаузою становили більшу кількість основної та контрольної групи і були молодого віку (від 37 до 45 років). Пацієнток в менопаузі було 13 осіб, а в постменопаузальному періоді - тільки 6 жінок.

Для оцінки інтенсивності головного болю застосовувалася візуально-аналогова шкала (ВАШ) від 1 до 10 балів відповідно. Використовувалися опитувальник за головним болем, опитувальник для виявлення вегетативних змін (Вейн А.М., 2000 р.), вегетативний індекс Кердо. Для оцінки астенічного стану застосовувалася суб'єктивна шкала оцінки астенії (MFI-20) $[2,6,7,9,14]$.

Всі пацієнтки проходили комплексне клінікопараклиническое обстеження, що включає в себе: неврологічний статус, електрокардіографію (ЕКГ), реоенцефалографію (РЕГ), ультразвукову доплерографію (УЗДГ), магнітно-резонансну (МРТ) або комп'ютерну томографію (КТ) головного мозку й шийного відділу хребта, вивчали висновки суміжних спеціалістів, ряд лабораторних показників і інше. Отримані результати порівнювалися с контрольною групою жінок в аналогічній віковій категорії.

Всі обстежені жінки були довільно розділені на 2 групи. До першої групи входило 32 жінки, які приймали препарат Цефавора протягом 2-х місяців у дозі 20 крапель 3 рази на день. Другу групу склали 20 жінок того ж віку, які не отримували регулярного медикаментозного лікування, періодично проходили курси фізіотерапії, масажу, лікувальної фізкультури.

У всіх пацієнток головні болі й ознаки вегетативної дистонії дебютували ще в пубертатному або молодому віці. 3 настанням пременопаузи, головні болі посилювалися, інтенсивність і частота їх збільшувались. Головні болі стискаючого, пульсуючого, розпираючого характеру, що локалізувалися частіше в тім'яній та лобово-скроневій ділянках, ірадиювали в потиличну частину голови, дифузно захоплювали всю голову. У 40,4\% випадків цефалгії супроводжувалися онімінням обличчя, верхніх кінцівок $(53,8 \%)$, слабкістю в руках і ногах $(9,6 \%)$, запамороченням $(73,1 \%)$, нестійкістю $(61,5 \%)$, фотофобією $(34,6 \%)$, нестабільними цифрами артеріального тиску $(88,5 \%)$, серцебиттям (42,3\%), болями в ділянці серця (30,8\%), відчуттям нестачі повітря, задишкою (55,8\%), почуттям жару або ознобу $(96,15 \%)$, метеоризмом $(78,8 \%)$, 
поліурією (82,7\%), болями в епігастрії (9,6\%), гіпергідрозом (локальним і дифузним) (100\%), набряком обличчя $(80,8 \%)$, страхом, тривогою $(59,6 \%)$, дратівливістю $(88,5 \%)$, зниженням працездатності $(94,2 \%)$, безсонням $(86,5 \%)$, загальною слабкістю $(96,2 \%)$, переднепритомним станом (13,5\%), поганою переносимістю високих і низьких температур (75\%), сонливістю $(28,8 \%)$, емоційною лабільністю (100\%), плаксивість (59,6\%), зниженням пам'яті та концентрації уваги $(82,7 \%)$. Такі стани мали нападоподібний або перманентний характер і провокувалися метеорологічними чинниками, емоційним або фізичним навантаженням. Також у пацієнток відзначалася схильність до депресії (9,6\%), нав’язливі ідеї (5,8\%), порушення лібідо (7,7\%), і т. д.

У неврологічному статусі у молодих пацієнток (від 37 до 45 років) відзначалася розсіяна неврологічна мікросимптоматика у вигляді порушення конвергенції й акомодації (90,9\%), анізорефлексії $(84,8 \%)$, пожвавлення сухожильних рефлексів $(72,7 \%)$, появи рефлексів орального автоматизму, стопних і кистьових знаків $(87,9 \%)$, парестезій $(84,4 \%)$, синдрому вегетативної дистонії (100\%), вестибуло-атактичного $(36,5 \%)$ і астенічного синдромів $(93,9 \%)$ і т. д.

У пацієнток старшого віку (з 45 до 55 років) приєднувалися явища пірамідної, екстрапірамідної й сенсорної недостатності більш вираженого характеру, елементи когнітивних порушень на тлі дисциркуляторної енцефалопатії (хронічної недостатності мозкового кровообігу й внутрішньочерепної гіпертензіі) і формування ознак, характерних для розвитку раннього атеросклерозу судин.

При вивченні інтенсивності головного болю за ВАШ до і після лікування, в основній групі відзначалася позитивна клінічна динаміка у вигляді значного зниження інтенсивності (65,6\% основної групи) головних болів , відносна стабілізація цифр артеріального тиску, менша залежність від метеорологічних, фізичних і психоемоційних факторів.

Оцінка інтенсивності цефалгічного синдрому за ВАШ представлена в табл. 3 .

Таблиия 3

Оцінка інтенсивності цефалгічного синдрому за BAIII

\begin{tabular}{|c|c|c|c|}
\hline $\begin{array}{c}\text { Основна } \\
\text { група }\end{array}$ & $\begin{array}{c}\text { Контрольна } \\
\text { група до } \\
\text { лікуванання }\end{array}$ & $\begin{array}{c}\text { Основна } \\
\text { група } \\
\text { після } \\
\text { лікування }\end{array}$ & $\begin{array}{c}\text { Контрольна } \\
\text { група } \\
\text { після } \\
\text { лікуваня }\end{array}$ \\
\hline $7,8 \pm 1,23$ & $7,5 \pm 1,10$ & $4,9 \pm 1,76$ & $7,1 \pm 1,64$ \\
\hline
\end{tabular}

Всім пацієнткам було проведено моніторинг основних суб'єктивних і об'єктивних симптомів до і після лікування в основній і контрольній групі (див. табл. 4.)

За даними опитувальника Вейна А.М. (2000р.) для виявлення наявності і ступеня вираженості вегетативних змін, в усіх пацієнток об'єктивні і суб'єктивні вегетативні симптоми спостерігалися частіше 3 переважанням симпатичної спрямованості, як перманентного $(48,1 \%)$ так і пароксизмального характеру
(51,9\%). У 12 пацієнток контрольної групи, а також в 19 пацієнток основної групи спостерігався змішаний перебіг нападів, без чіткого типу. Після проведеного курсу лікування через 2 місяці в основній групі відзначалася позитивна динаміка у вигляді зменшення вегетативних симптомів, частоти та інтенсивності головних болів, нормалізації вегетативних функцій, нормалізації сну, працездатності, зменшення пітливості, серцебиття, а також зменшення частоти, тривалості і вираженості вегетативних пароксизмів. Показники опитувальника А.М. Вейна корелювали з клінічною симптоматикою, представленою в табл. 4.

Таблиия 4

Порівняльна характеристика клінічних симптомів

\begin{tabular}{|c|c|c|c|c|}
\hline Скарги & 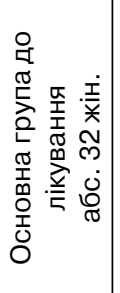 & 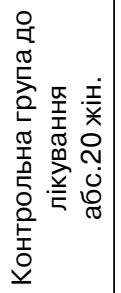 & 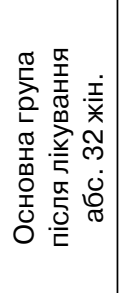 & 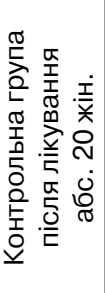 \\
\hline Головний біль & $100 \%$ & $100 \%$ & $34,4 \%$ & $90 \%$ \\
\hline $\begin{array}{l}\text { Оніміння в області об- } \\
\text { личчя }\end{array}$ & $62,5 \%$ & $45 \%$ & $46,9 \%$ & $40 \%$ \\
\hline $\begin{array}{l}\text { Оніміння у верхніх } \\
\text { кінцівках }\end{array}$ & $43,8 \%$ & $45 \%$ & $37,5 \%$ & $45 \%$ \\
\hline Головокружіння & $71,9 \%$ & $65 \%$ & $53,1 \%$ & $60 \%$ \\
\hline $\begin{array}{l}\text { Нестабільні цифри } \\
\text { артеріального тиску }\end{array}$ & $84,4 \%$ & $85 \%$ & $53,1 \%$ & $80 \%$ \\
\hline Серцебиття & $65,6 \%$ & $65 \%$ & $46,9 \%$ & $45 \%$ \\
\hline Біль в ділянці серця & $56,3 \%$ & $55 \%$ & $50 \%$ & $55 \%$ \\
\hline Біль в епігастрії & $18,8 \%$ & $10 \%$ & $15,6 \%$ & $10 \%$ \\
\hline $\begin{array}{l}\text { Відчуття браку повітря, } \\
\text { задишка }\end{array}$ & $53,1 \%$ & $50 \%$ & $31,3 \%$ & $55 \%$ \\
\hline Відчуття жару або ознобу & $84,4 \%$ & $60 \%$ & $59,4 \%$ & $60 \%$ \\
\hline Поліурія & $59,4 \%$ & $60 \%$ & $40,6 \%$ & $60 \%$ \\
\hline $\begin{array}{l}\text { Гіпергідроз (локальний } \\
\text { або дифузний) }\end{array}$ & $93,8 \%$ & $90 \%$ & $68,8 \%$ & $95 \%$ \\
\hline Набряклість обличчя & $37,5 \%$ & $35 \%$ & $28,1 \%$ & $35 \%$ \\
\hline Страх, тривога & $56,3 \%$ & $50 \%$ & $40,6 \%$ & $50 \%$ \\
\hline Дратівливість & $78,1 \%$ & $80 \%$ & $62,5 \%$ & $85 \%$ \\
\hline $\begin{array}{l}\text { Зниження } \\
\text { працездатності }\end{array}$ & $93,8 \%$ & $100 \%$ & $56,3 \%$ & $95 \%$ \\
\hline Безсоння & $84,4 \%$ & $70 \%$ & $25 \%$ & $70 \%$ \\
\hline Загальна слабкість & $71,9 \%$ & $65 \%$ & $31,25 \%$ & $60 \%$ \\
\hline $\begin{array}{l}\text { Погана переносимість } \\
\text { високих і низьких тем- } \\
\text { ператур }\end{array}$ & $75 \%$ & $75 \%$ & $43,8 \%$ & $70 \%$ \\
\hline Переднепритомний стан & $21,9 \%$ & $20 \%$ & $15,6 \%$ & $20 \%$ \\
\hline Сонливість & $28,1 \%$ & $25 \%$ & $25 \%$ & $25 \%$ \\
\hline Емоційна лабільність & $100 \%$ & $100 \%$ & $28,1 \%$ & $80 \%$ \\
\hline Плаксивість & $56,3 \%$ & $60 \%$ & $42,4 \%$ & $55 \%$ \\
\hline $\begin{array}{l}\text { Зниження пам'яті та } \\
\text { концентрації уваги }\end{array}$ & $87,5 \%$ & $70 \%$ & $34,4 \%$ & $65 \%$ \\
\hline
\end{tabular}


За даними розрахунку вегетативного індексу Кердо, до початку дослідження симпатичний вплив спостерігался у 30,8\% жінок основної і 9,6\% контрольної груп, парасимпатическое переважання у 13,5\% (контрольна - 15,4\%), нормотония - 17,3\% (контрольна $-13,5 \%)$. Після проведеного курсу лікування через 2 місяці в основній групі збільшилася кількість жінок $з$ нормотонією - 43,75\%, зменшилася кількість симпатикотоній $(34,3 \%)$ і парасимпатикотоній $(21,9 \%)$. Показники в контрольній групі через 2 місяці корелювали з аналогічними показниками у жінок в цій же групі до початку лікування.

Таким чином, вивчення вегетативного тонусу дало можливість виявити зниження вираженості симпатикотонії в процесі лікування препаратом Цефавора. На тлі лікування відзначалося зменшення симпатичної спрямованості вегетативних функцій, про що свідчить регрес клінічних проявів, а також нормалізація вегетативного індексу Кердо і збільшення кількості пацієнток з нормотонією.

При вивченні вираженості астенічного синдрому за допомогою суб'єктивної шкали оцінки астенії (MFI-20) в основній і контрольній групах до початку дослідження відзначалася вираженість загальної астенії, зниження загальної активності, мотиваційних процесів, наявність фізичної та психічної астенії. В процесі динамічного спостереження через 2 місяці в основній групі відзначалися поліпшення в стані жінок, зниження вираженості важкості астенії, розумової та фізичної стомлюваності, загальної астенізації.

До початку дослідження при проведенні ЕКГ у 18 пацієнток реєструвалися ознаки гіпертрофії міокарда лівого шлуночка, у 30 пацієнток відзначалися неспецифічні зміни при відсутності морфологічних змін в міокарді, які були обумовлені частіше підвищенням тонусу симпатичного відділу вегетативної нервової системи (синусова тахікардія, синусова аритмія, екстрасистолія), що підтверджувалося даними дослідження різних авторів [6-10]. При проведенні ЕКГ в динаміці були зареєстровані позитивні зміни в основній групі обстежуваних жінок, які приймали препарат Цефавора. У 11 пацієнток з 32 відзначалася нормалізація серцевого ритму, зменшилися екстрасистоли. За даними дослідження артеріального тиску в основній і контрольній групах, у більшості пацієнток відбулася стабілізація цифр артеріального тиску до межах вікової норми .

Для вивчення церебральної гемодинаміки ми використовували методи реоенцефалографії (РЕГ) та ультразвукової доплерографії (УЗДГ).

У пацієнток в основній і контрольній групі до лікування показники церебральної гемодинаміки за даними РЕГ (реоенцефалографія) були ідентичні і характеризувалися порушенням конфігурації анакротичної та катакротичної фаз хвилі, пологого характеру висхідної частини, зниження рівня дикротичного зубця й верхівки, роздвоєння вершини 3 утворенням плато, поява венозних хвиль на катакротичній фазі, що свідчило про достовірні зміни еластотонічних властивостей судинної стінки та про ознаки утруднення венозного відтоку різного сту- пеня вираженості в усій групі обстежених хворих. Найчастіше превалював гіпертонічний тип кривої (82,7\%) з проявами межпівкульної асиметрії та ознаками венозного застою, поєднанням елементів, характерних для гіпертонічного типу РЕГ - кривої.

Після проведеного курсу лікування препаратом Цефавора через 2 місяці в основній групі в усіх 32 пацієнток відзначалися зміни якісних показників кривих РЕГ у вигляді зменшення плато, нормалізації систоло-діастолічного співвідношення, зменшення кількості венозних хвиль, що підтверджує вазоактивні дії препарату Цефавора, вірогідно, за рахунок покращення мікроциркуляції, венозного відтоку та реологічних властивостей крові.

Для детального вивчення церебральної гемодинаміки нами використовувався метод УЗДГ, при використанні якого у 88,5\% пацієнток відзначалося достовірне зниження швидкості кровотоку підвищення індексу пульсації по всіх судинних басейнах з більш вираженою дисциркуляцією в вертебробазилярному басейні. До процесу залучалися не тільки внутрішньомозкові, але й магістральні судини голови, що надалі сприяло розвитку більш глибоких порушень церебральної гемо- та ліквородинаміки i прогресуванню більш вираженої енцефалопатії. У незначної кількості більш молодих пацієнток (5,8\%) швидкісні характеристики збігалися з нормальними показниками, що, можливо, було пов'язано з включенням компенсаторних механізмів у інтракраніальних судинах у вигляді вазоспазму для забезпечення мозкового кровотоку на нормальному рівні.

Результати досліджень через 2 місяці показали, що при УЗДГ було виявлено підвищення швидкісних показників кровотоку на $15-20 \%$ в хребтових артеріях, задніх мозкових та середніх мозкових артеріях. При цьому відзначаються підвищення коефіцієнтів судинної реактивності, позитивна реакція на функціональні навантажувальні тести, що відповідає задовільній величині церебрального резерву за даними дослідження з використанням гіпер- і гиповентиляційних тестів. Ознак вираженого стенозу й оклюзії в магістральних судинах виявлено не було. Відзначалося поліпшення кількісних і якісних параметрів спектра в усіх судинних басейнах, непрямі ознаки поліпшення церебрального венозного кровотоку без гемодинамічно значущих відхилень . Показники РЕГ та УЗДГ в контрольній групі істотно не відрізнялися від вихідних. Таким чином, ці дані вказують на ефективність застосування препарату Цефавора, який, за допомогою комбінованого поєднання гінкго білоба, глоду й омели білої, покращує реологічні характеристики крові та швидкість церебрального кровотоку, володіє вазоактивною, антиагрегантною і венотонізуючою дією.

При вивченні даних дослідження КТ і МРТ в анамнезі, в обох групах не було виявлено вираженої судинної, а також демієлінізуючої, запальної й вогнищевої патології. Відзначалося незначне розширення субарахноїдальних просторів і шлуночкової системи мозку, симетричне зниження щільності тканини головного мозку. 


\section{Висновки}

Таким чином, при спостереженні за жінками в пременопаузі та при перших ознаках менопаузи доцільно виділяти групу ризику пацієнток стосовно цефалгічного синдрому на тлі вегетативної дистонії. Таким пацієнткам доцільно рекомендувати періодичні курси прийому препарату рослинного походження Цефавора в монотерапії або в складі комплексного лікування .

Препарат не має виражених побічних явищ (крім індивідуальної чутливості) при тривалому прийомі. Тільки у 5 пацієнток з основної групи на початку курсу лікування відзначалося посилення головного болю протягом 3-4 днів, які припинились самостійно і не вимагали відміни Цефавори. У 3 пацієнток періодично зазначалося поява загальної слабкості, «несвіжості в голові» «ватності у всьому тілі», легке запаморочення. Ймовірно, це було пов'язано з особливістю дії гомеопатичних препаратів на початковому етапі лікування.

Препарат Цефавора може використовуватися як альтернатива або доповнення до синтетичних препаратів, ефективний і досить безпечний при тривалому прийомі.

Авторам хотілося 6 нагадати лікарям різних спеціальностей - терапевтам, неврологам, ендокринологам та іншим, що обстежуючи жінку з вікової категорії «40 +» 3 проявами вегетативної дисфункції, доцільно спрямувати іï до гінеколога для оцінки та корекції гормонального фону.

Список використаной літератури

1. Березина И.И. Менопауза. - М.: Медицина, 2002. C. $5-12$.

2. Головная боль Текст. : рук-во для врачей / Под ред. М. Н. Пузина. - М.: Медицина, 2007. - С. 3-203.

3. Клопова И.А. Клинико-функциональная характеристика, особенности ведения женщин с цефалгическим синдромом в климактерическом периоде // Автореф. дис.. канд. мед. наук. Иваново. 2008. - 27 с.

4. Краснощекова Л.И. Неврологические нарушения при патологическом климаксе у женщин// Журн. невропатологии и психиатрии им. С.С. Корсакова. - М.: Медицина, 1989. - T. 89. - C. $41-44$.

5. Кулаков В.И., Сметник В.П. Руководство по климактерию. - М.: Медицина, 2001. - С. 265.

6. Мачерет Е.Л., Коркушко А.О. Вегетососудистая дистония и рефлексотерапия // Международный неврологический журнал. - 2009. — № 8(30). - С. 69-71.

7. Морозова О.Г. Вегетативные дисфункции в общесоматической практике // Здоров’я України (тематичний випуск), 2007.- C. 38 - 39 .

8. Синицына Л.В. Клинико-функциональная характеристика неврологической патологии у женщин в климактерическом периоде, особенности ее диагностики и диспансеризации в амбулаторно-поликлинических условиях / Автореф. дис.. докт. мед. наук. Иваново, 2006. - 23 с.

9. Соколов С.А. Алгоритм объективной оценки результатов лечения больных с нейроциркуляторной дистонией: обоснование и опыт применения / С.А. Соколов // Рос.

медико-биол. вестн. им. акад. И.П. Павлова. - 2010. №4.- С. $104-109$.

10. Состояние вегетативной нервной системы при цефалгиях в климактерическом периоде / И. А. Клопова // Вестн. РГМУ. - 2008. - № 2 (61). - С. 31.

11. Состояние психовегетативного статуса у женщин с цефалгиями в период перименопаузы / И. А. Клопова // Вестн. Ивановской медицинской академии. - 2007. - Т. 12, № $1-2 .-$ C. $41-43$.

12. Завальная Е. П., Тондий О. Л., и соавт. Монотерапия препаратами Гинкго Билобы в лечении вегетативно-сосудистых расстройств у женщин в период пре- и менопаузы // Украинский вестник психоневрологии. - 2012. - Т. 20.Вип.3 (72). - С. 96.

13. Цефалгический синдром в климактерическом периоде у женщин / И. А. Клопова, Л. И. Краснощекова, Н. Ф. Евсеев, М. Ю. Точенов, В. Л. Ельниковский, В. Б. Гринштейн, В. В. Линьков // IX Всероссийский съезд неврологов: Сборник тезисов. - Ярославль, 2006. - С. 14.

14. Шток В. Н. Головная боль. - М. : ООО «МИА», 2007. $274 \mathrm{c}$.

15. «For the support of blood flow - Cefavora ${ }^{\oplus}$. Results of a multicentre drug monitoring». Jürgen Hartmann Verlag GmbH, D-91093 Heßdorf-Klebheim. Editorial staff: A. Bauer, B. Blunck. Enclosure to DBI - Der Bayerische Internist 4/08, August/September 2008.

16. Sieglaff V.: Beginnende zerebrovaskuläre Insuffizienz Behandlung mit Cefavora ${ }^{\circledR}$, Z. Allg. Med. 67, 1593-1598 (1991).

\title{
Лечение неврологических расстройств у женщин в периоде пре- и менопаузы с использованием комплексных гомеопатических препаратов
}

\author{
Проф. Т.А. Литовченко, доц. О.Л. Тондий, доц. О.П. Завальная \\ Харьковская медицинская академия последипломного образования
}

Нами проводилась оценка эффективности действия гомеопатического препарата Цефавора (Cefak, Германия) в коррекции головной боли при вегетососудистой дистонии у женщин в период пре- и менопаузы. В группу обследованных вошли 50 женщин в возрасте от 37 до 55 лет, у которых имели место цефалгии различного генеза, а также проявления вегетативной дистонии. Всем больным проводились общеклиническое, неврологическое и психологическое обследования. Предложенный препарат объединяет вазоактивное, венотонизирующее, нейропротекторное, кардиотоническое действие, улучшает реологические свойства крови и микроциркуляцию. В результате лечения отмечалась положительная динамика в клинической картине, в виде уменьшения интенсивности цефалгического синдрома, а так- 
же нормализация вегетативных функций у женщин в период пре- и менопаузы. Препарат Цефавора возможно рекомендовать для периодических курсов в монотерапии или в комплексном лечении.

Ключевые слова: цефалгический синдром, вегетативная дистония, пре- и менопауза у женщин, Цефавора.

\section{Treatment of neurological disorders of women in the period of pre- and menopausal using complex homeopathic drugse}

Prof. T.A. Litovchenko, PHD O.L. Tondiy, PHD O.P. Zavalnaya

Kharkov Medical Academy of Postgraduate Education

We evaluated the efficacy of a homeopathic drug Cefavora (Cefak, Germany) in the correction of headaches with dystonia in women during pre- and menopause. The studied group included 50 women aged 37 to 55 years who were cephalalgia various origins and manifestations of vegetative dystonia. All patients underwent clinical, neurological and psychological examination. The proposed formulation combines vasoactive, veno-tonic, neuroprotective, cardiotonic effect, improves blood rheology and microcirculation. As a result, the treatment of positive dynamics in the clinical picture, as a decrease in intensity cephalgic syndrome, as well as normalization of autonomic function in women during pre- and menopause. Cefavora may be recommended for periodic courses in monotherapy or combined treatment.

Key words: cephalgic syndrome, vegetative dystonia, pre- and menopausal women Cefavora.

Контактна інформація: Літовченко Тетяна Анатоліївна зав. кафедрою невропатології та дитячої неврології ХМАПО, доктор медичних наук, професор. м. Харків, вул. Балакірєва, 5, м. т. 067-736-66-09, 067-298-92-33, e-mail: neurosurgery@med.edu.ua.

Стаття надійшла до редакції 16.10.2014 p.

ПИТАННЯ ГАСТРОЕНТЕРОЛОГІЇ. СИМПОЗІУМ

УДК 616.329-002-07-036.2-039
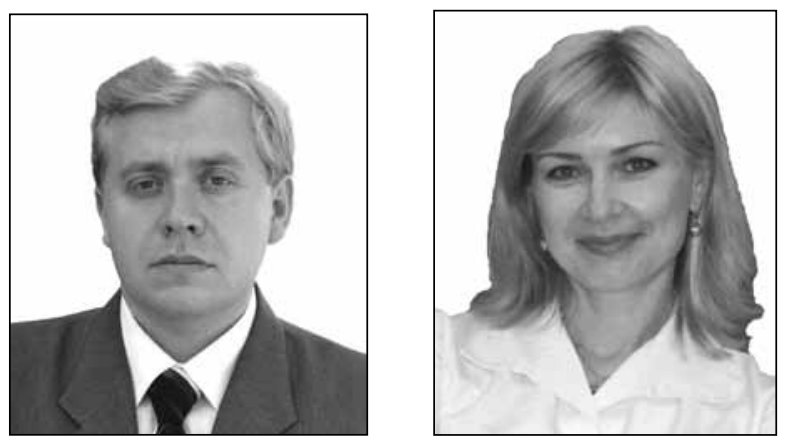

Проф. А.А. Опарин,

доц. Н.В. Лаврова

Харьковская медицинская академия

последипломного образования

Кафедра терапии, ревматологии

и клинической фармакологии

\section{Гастроэзофагеацьная рефмюксная болезнь. Проблематика. Аиагностика. Аечение}

$\mathrm{B}$ последние годы среди заболеваний не только пищеварительного тракта, но и клиники внутренних болезней в целом, особое место стала занимать гастроэзофагеальная рефлюксная болезнь (ГЭРБ) [6, $7,13,38]$.

Гастроэзофагеальная рефлюксная болезнь (К 21) - это хроническое рецидивирующее заболевание, обусловленное спонтанным, регулярно повторяющимся забросом в пищевод желудочного и/или дуоденального содержимого, приводящим к повреждению дистального отдела пищевода и появлению характерных симптомов (изжога, ретростернальные боли, дисфагия).

Примечательно, что еще $40-50$ лет назад о таком заболевании никто не говорил вообе, и буквально за считанные годы оно стало занимать одно из ведущих мест по распространению, поражению лиц молодого и среднего возраста, количеству осложнений, что обуславливает не только медицинское, но и социальное значение этой проблемы $[13,27,35]$.

Особую проблематику данного заболевания обуславливают и следующие факторы: 